\title{
Improvement in Adhesive Performance of Single-Lap Joining Composite Lamınates by Using Nano-Montmorillonite Modified Epoxy
}

\author{
Hasan ULUS, Halil Burak KAYBAL, Okan DEMİ, Muhammet Ali SENYURT, Ahmet Caner TATAR, \\ Ahmet AVCI
}

Selcuk University, Faculty of Engineering, Department of Mechanical Engineering, 42000 Konya,

Turkey; hasanulus@selcuk.edu.tr

\begin{abstract}
Nanoparticles have been widely used as reinforcing materials related to polymer matrices for outstanding performance. In this paper expresses modified epoxy adhesives which are enhanced conventional adhesives widely used in industry. In this study, nano-montmorillonite (nano-MMT) (1\% to 5\% by weight) was mixed into the epoxy resin by using ultrasonication to obtain toughened adhesives. Carbon fiber reinforced composites was used as adherent material and it's were prepared according to ASTM D5868-01. It has been clearly revealed that the additions of low concentrations of nanosized particles ( $2 \%$ by weight) performed higher mechanical strength than others and also show lower adhesive performance with increased nano-MMT weight percentage. According to the lap shear test results, shear strength was significantly increased with addition of $2 \mathrm{wt} \%$ nano-MMT and the strengths of the joints were found to be $12.5 \%$ higher than neat epoxy adhesives.
\end{abstract}

Keywords: Single-lap joints; nano-montmorillonite; nano adhesives; epoxy; composite

\section{Tek Taraflı Bindirme Bağlantısıyla Birleştirilen Tabakalı Kompozitlerin Yapıştırma Performansının Nano-Montmorillonit Modifiyeli Epoksi Kullanılarak İyileștirilmesi}

\begin{abstract}
Özet: Nanoparçacıklar üstün performanslarından dolayı polimer matrislerde takviye malzemeleri olarak yaygın şekilde kullanılmaktadır. Bu çalışmada, endüstride yaygın olarak kullanılan modifiye edilerek geliştirilmiş epoksi yapıştırıcılar ele alınmıştır. Bu amaçla yüksek tokluğa sahip yapıştırıcılar elde etmek üzere epoksi reçine içerisine nano-montmorillonit (nano-MMT) ilave edilerek (ağırlıkça \% 1-5) ultrasonik karıştırıcı ile karıştırılmıştır. Yapıştırılacak malzeme olarak karbon elyaf takviyeli kompozitler kullanılmış ve bunlar ASTM D5868-01 standartına göre hazırlanmıştır. Nanoparçacıkların düşük konsantrasyonlarda (ağırlıkça \% 2) epoksi içerisine eklenmesinin, diğerler oranlardan daha iyi mekanik dayanım sağladığı ve artan nano-MMT ağırlık yüzdesi ile birlikte daha düşük yapışma performansı gösterdiği açık bir şekilde görülmüştür. Test sonuçlarına göre kesme dayanımı \% 2 (ag) nano-MMT ilavesi ile önemli ölçüde artmış ve mukavemetlerinde saf epoksi yapıştırıcılara kıyasla \% 12.5 artış gözlenmiştir.
\end{abstract}

Anahtar kelimeler: Tek taraflı bindirme bağlantısı; nano-montmorillonite; nano yapıștırıc1; epoksi; kompozit 


\section{Introduction}

Polymeric adhesives provide practical solutions to the production of complex composite parts compared with the more traditional methods such as bolting, brazing, welding, and mechanical fastening. Polymer adhesives such as epoxies are commonly used to join composite parts [1-3].

Epoxy adhesive bonding provides many advantages such as low cost, high strength to weight ratio, low stress concentration, fewer processing requirements and superior fatigue resistance and environmental resistance. For these reasons, epoxies are widely used in the automobile, aerospace, construction, marine and electronics industries [2, 3]. However, the adhesives are usually much weaker than the adherents. In additionally, epoxies have low strain capability due to their brittle structure. To improve the bonding performance and enhance adhesion strength and thermal stability, one possibility is nanoparticle adding into epoxy to obtain toughened adhesives. For this purpose, different types of nanoparticles such as carbon nanotubes (CNTs), nano-SiO 2 (silica), and nano- $\mathrm{Al}_{2} \mathrm{O}_{3}$ (alumina) have been utilized [4]. In this work, we investigate the effect of nanomontmorillonite (nano-MMT), on the lap shear strength and elongation at break of epoxy adhesives.

\section{Method}

In this study, carbon fiber laminated composites adherents were firstly produced. Then epoxy based nano adhesives were prepared and adherents were joined. The epoxy resin as the commercially available diglycidylether of bisphenol-A (DGEBA) supplied by Momentive Hexion Inc. Carbon fiber fabric and the all other vacuum infusion equipments were provided by Dost Kimya Inc. A commercial grade of nano- montmorillonite (nano-MMT) was provided by ESAN Eczacibasi. The area density of carbon fiber was $300 \mathrm{~g} / \mathrm{m}^{2}$ and each bundle consisted of 12000 filament. Carbon fiber reinforced epoxy matrix laminated nanocomposite panel was prepared by means of VARTM $[5,6]$. Finally, the cured panel was taken out and specimens were cut according to recommended dimension $(100 \mathrm{~mm} \times 25 \mathrm{~mm} \times 3 \mathrm{~mm})$ as indicated in Standard Test Method for Lap Shear Adhesion for Fiber Reinforced Plastic Bonding (ASTM D5868-01) standards.

Adhesive areas were signed as $25.4 \mathrm{~mm} \times 25.4 \mathrm{~mm}$ and abraded with silicon carbide paper to roughen the adhesive surfaces. Then specimens immersed in acetone to remove any dust and dry at $35{ }^{\circ} \mathrm{C}$ for $10 \mathrm{~min}$.

The nano-adhesives were prepared by addition of epoxy resin to achieve 1, 2, 3, 4 and 5 wt $\%$ nanoMMT content (seen in Fig.1.a). The epoxy-MMT mixture was mixed via ultra sonicator for $30 \mathrm{~min}$ and degassed in a vacuum oven $25^{\circ} \mathrm{C} / 0.6$ bar for $20 \mathrm{~min}$. The hardening agent was added into the mixture according to supplier instructions. The prepared adhesives were glair on the sanded surface and then it was kept until become gelate form.

After drying these adherents until become gelate form, laminated composite specimens were superimposed. Composite alignment tabs were also bonded to the epoxy adhesive (seen in Fig.1.b). Pressed down via clamp after assembly, the specimens were cured in the vacuum oven $100{ }^{\circ} \mathrm{C}$ for 3 hours.

All specimens were tested using an Instron 8801 testing machine at room temperature. The crosshead-loading rate was adjusted as $1 \mathrm{~mm} / \mathrm{s}$ (seen in Fig.1.c). 

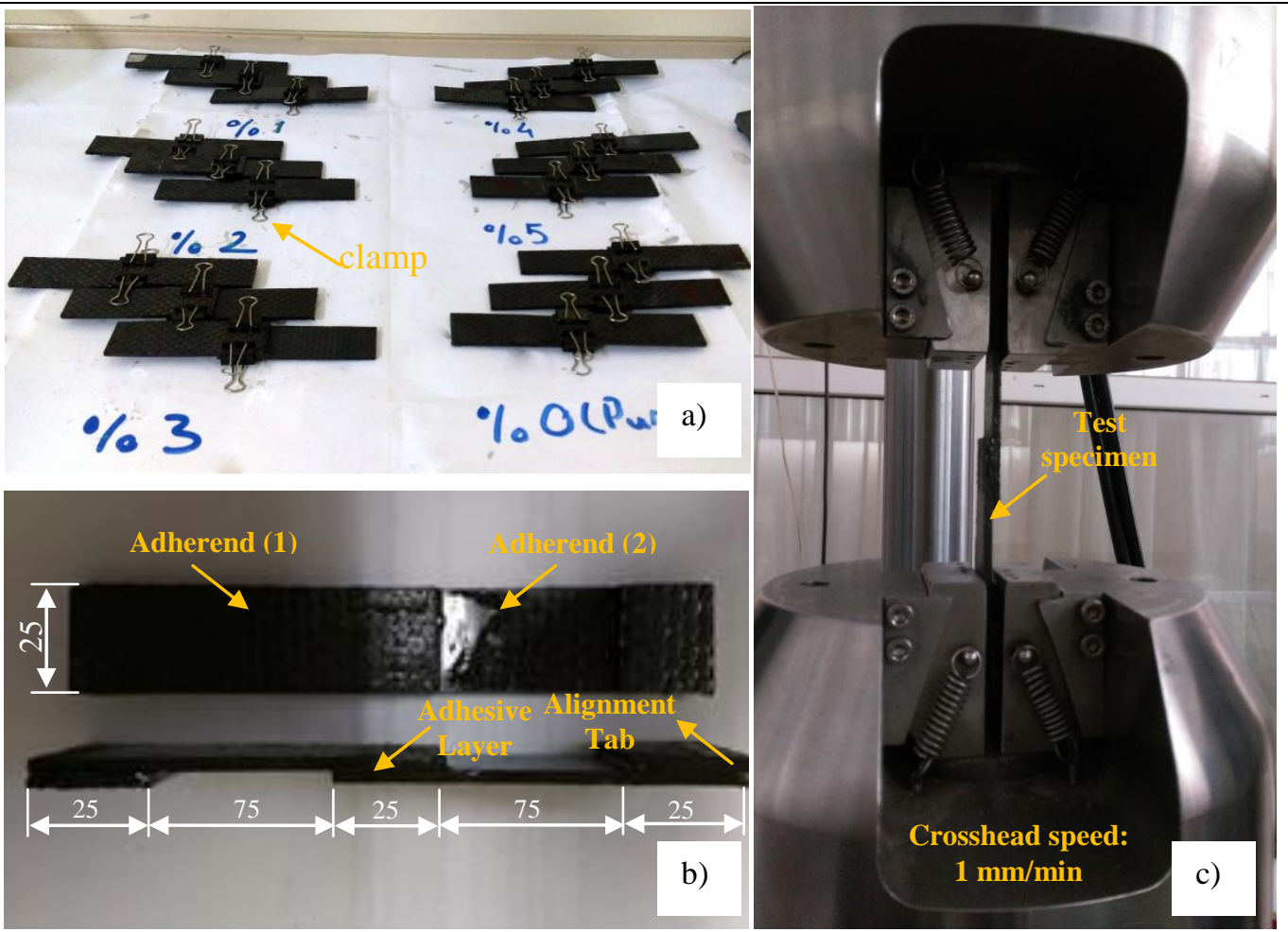

Fig. 1. (a) Single lap joint composite specimens, (b) front and bottom view of specimens,

(c) Typical test setup of single lap joint

\section{Results and Discussion}

Tensile lap shear tests were carried out according to ASTM-D5868-01 standard. Fig. 2a shows that load and strain curves of single lap specimens. 2 wt\% nano MMT-Epoxy adhesive is seen optimum concentration to obtain well properties.

Bar graph also depicts that the measured load during lap joint test in Fig 2.b. It is clearly seen from this figures, the load increase by 1 and $2 \mathrm{wt} \%$ however, the load decreases by 3,4 and $5 \mathrm{wt} \%$.
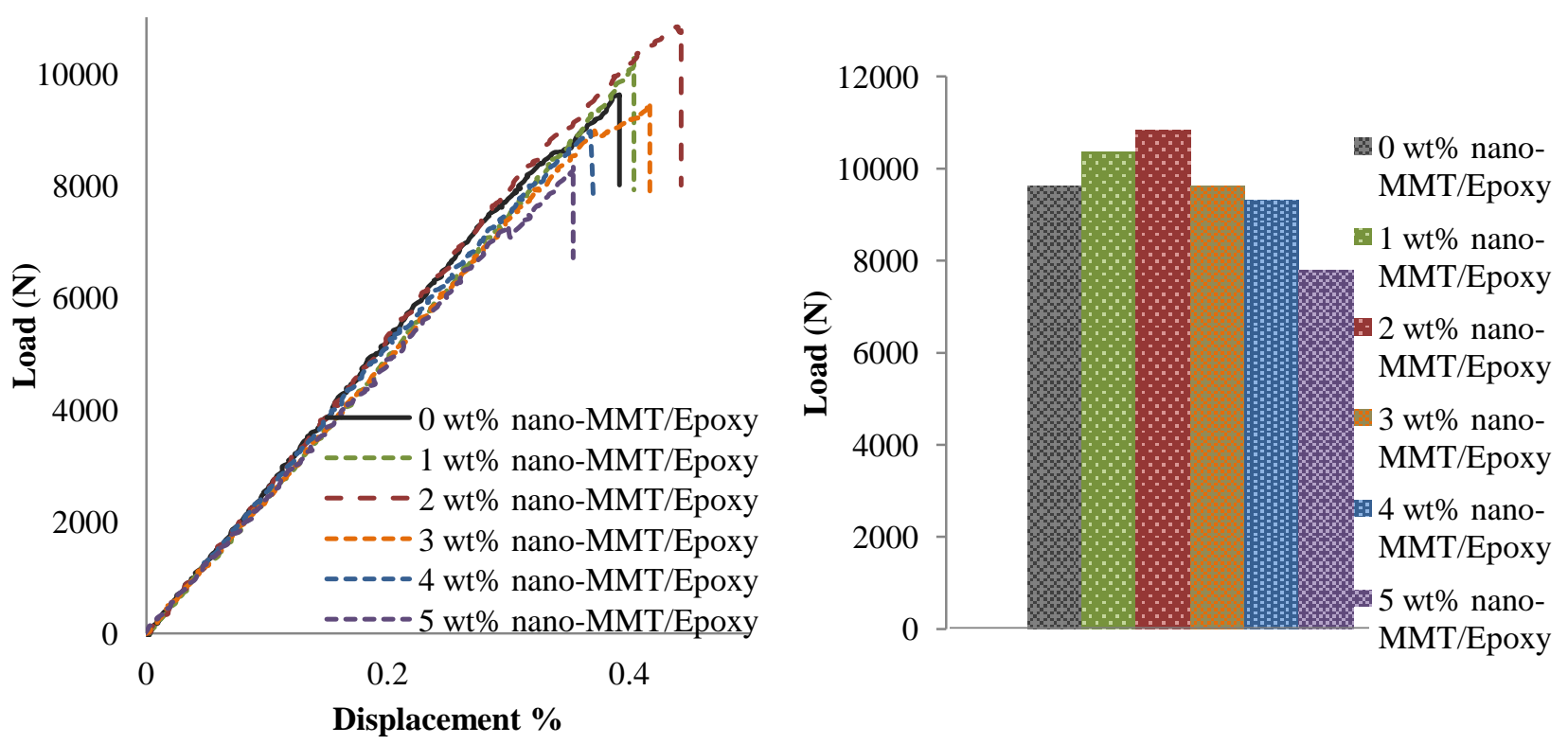

Fig. 2. (a) Load-displacement curves of composite single lap joints, (b) load variation values 
Optical micrograph observations (Fig. 3) show that neat adherent exhibit poor joining ability with the proof of fiber pull out mechanism in Fig. 3a. Effectively good adhesion is also seen in image of $2 \mathrm{wt} \%$ nano-MMT epoxy adherent with the evidence of plastic deformation signs (Fig. 3.c). On the other hand, especially $4 \mathrm{wt} \%$ and $5 \mathrm{wt} \%$ nano - MMT adding leads to poor joining properties. It is clearly seen that crack doesn't propagate in the epoxy adhesive layer.
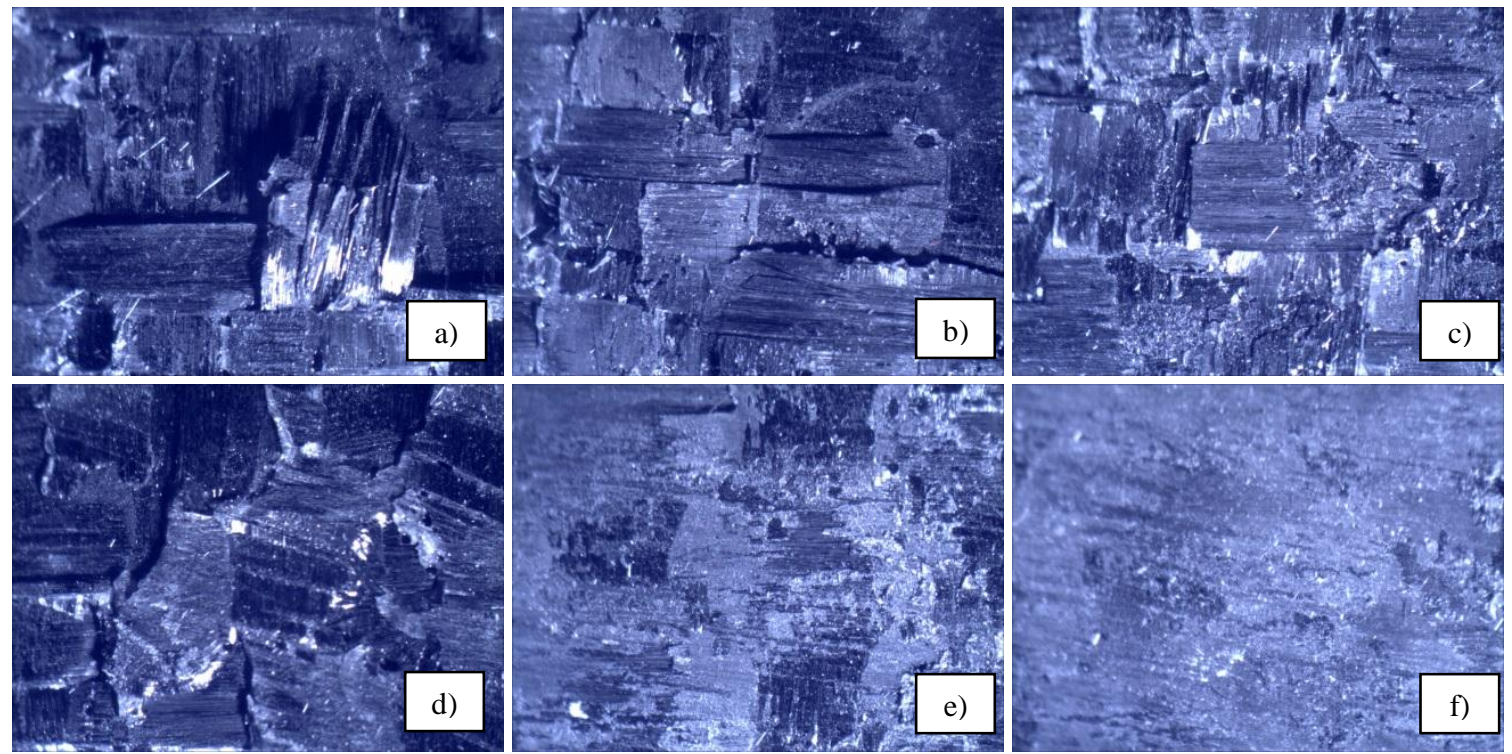

Fig. 3. Optical microscope images of the fracture surfaces of single lap joining composite specimens;

a) neat epoxy adherent, b) $1 \mathrm{wt} \%$ nano-MMT epoxy adherent, c) $2 \mathrm{wt} \%$ nano-MMT epoxy adherent,

d) $3 \mathrm{wt} \%$ nano-MMT epoxy adherent, e) $4 \mathrm{wt} \%$ nano-MMT epoxy adherent, f) $5 \mathrm{wt} \%$ nano-MMT epoxy

Fig. 4 shows typical SEM images of the fracture surfaces of single lap joining composite specimens. As shown in Fig. 4.b, the fracture surface is relatively rough and there is little evidence of plastic deformation. The matrix plastic deformation is negligible compared to that observed in Fig. 4.a. This explains that the nano-MMT adding increase toughness.
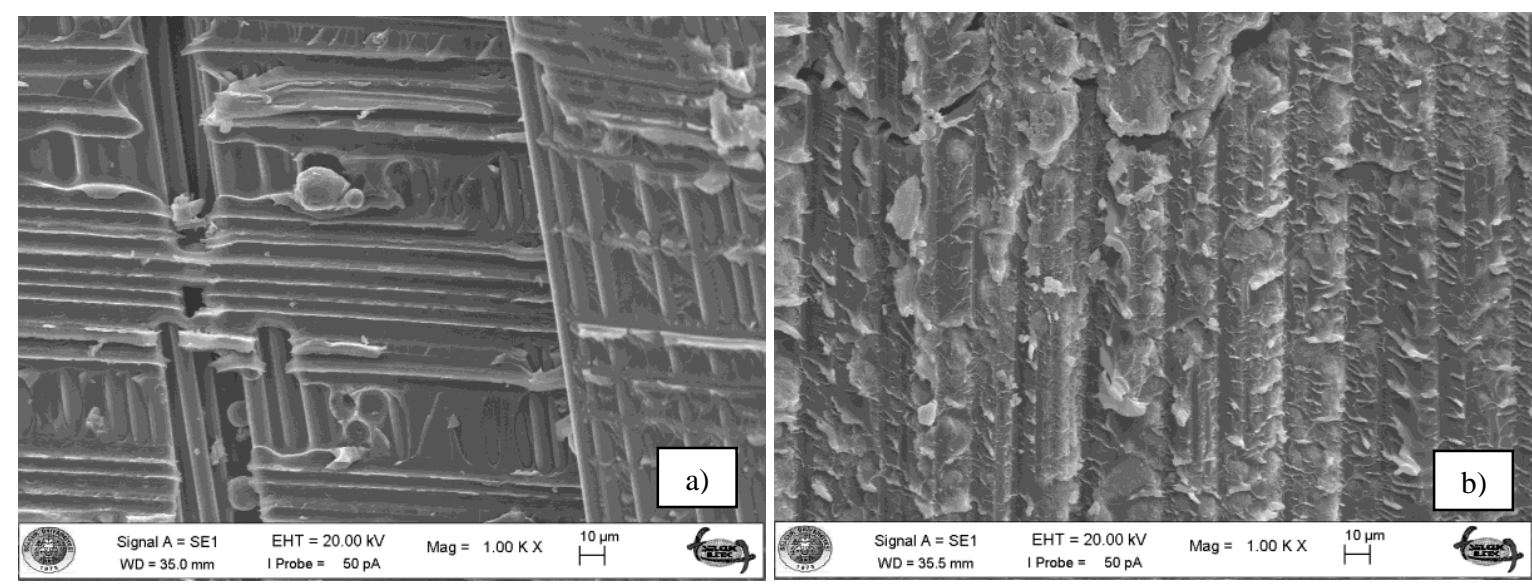

Fig.4. SEM images of the fracture surfaces of single lap joining composite specimens;

a) neat epoxy adherent, b) $2 \mathrm{wt} \%$ nano-MMT epoxy adherent

\section{Conclusion}

The effects of incorporating nano-MMT into epoxy were studied in terms of their adhesive 
behaviours. According to the performed study, nano-MMT modified epoxies (1 wt $\%$ and $2 \mathrm{wt} \%$ ) displayed increased adhesive performance. Incorporation of $2 \mathrm{wt} \%$ nano-MMT into epoxy improved the adhesive joint strength by $12.5 \%$. However, $4 \mathrm{wt} \%$ and $5 \mathrm{wt} \%$ nano-MMT decreased adhesive properties.

\section{References}

[1] Hsiao, K.-T., J. Alms, and S.G. Advani, Use of epoxy/multiwalled carbon nanotubes as adhesives to join graphite fibre reinforced polymer composites. Nanotechnology, 2003. 14(7): p. 791.

[2] Kinloch, A., Toughening epoxy adhesives to meet today's challenges. MRS bulletin, 2003. 28(6): p. 445-448.

[3] Armstrong, K. and R. Barrett, Care and repair of advanced compositesSociety of Automotive Engineers. Warrendale, USA, 1998.

[4] Mansourian- Tabaei, M., S.H. Jafari, and H.A. Khonakdar, Lap shear strength and thermal stability of diglycidyl ether of bisphenol a/epoxy novolac adhesives with nanoreinforcing fillers. Journal of Applied Polymer Science, 2014. 131(6).

[5] Ulus, H., Ö.S. Şahin, and A. Avc1, Enhancement of flexural and shear properties of carbon fiber/epoxy hybrid nanocomposites by boron nitride nano particles and carbon nano tube modification. Fibers and Polymers, 2015. 16(12): p. 2627-2635.

[6] Ulus, H., et al., Low-velocity impact behavior of carbon fiber/epoxy multiscale hybrid nanocomposites reinforced with multiwalled carbon nanotubes and boron nitride nanoplates. Journal of Composite Materials, 2016. 50(6): p. 761-770. 